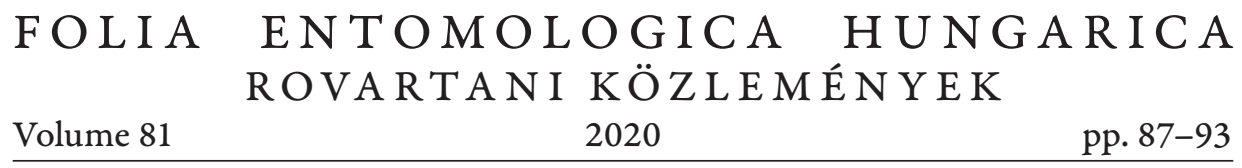

\title{
A new species of Eptacus Desbrochers des Loges, 1908 from Syria (Coleoptera: Curculionidae: Entiminae)
}

\author{
Valentin SzÉNÁsI \\ Duna-Ipoly National Park Directorate, H-1121 Budapest, Költö utca 21., Hungary. \\ E-mail:szvalent@gmail.com.
}

\begin{abstract}
Eptacus cylindriclavatus sp. n. is described from Syria, compared with similar congeners, and main diagnostic characters are figured. The new species was discovered near the city of Palmyra. It is relatively easily recognizable by the shape of the antennal club and rostrum. With 16 figures.
\end{abstract}

Key words - Holcorhinini, Middle East, taxonomy, biodiversity

\section{INTRODUCTION}

The genus Eptacus Desbrochers des Loges, 1908 currently contains seven species and two subspecies (Alonso-ZARAZAGA et al. 2017). It is distributed in the Middle East, but some species are known from the eastern Mediterranean and Northern Africa. Only a few authors dealt with the genus, describing the known species (STIERlin 1861, Marseul 1868, Peyerimhoff 1907, Reitter 1908, EMden 1928, Lona 1939, Pelletier 2006). The classification of the genus and the tribe Holcorhinini Desbrochers des Loges, 1898 is problematic, and is not yet completely settled, as discussed in more details in the last revision (PELletier 2006,2012 ). Further work is difficult to do because the current political situation of the Middle East makes it impossible to collect new specimens.

During a 2010 collecting trip Hungarian coleopterists collected a series of Eptacus specimens which represent a new species of the genus.

\section{MATERIAL AND METHODS}

Morphological terminology follows LyAL (2019). Body length was measured from the anterior edge of the eyes to the elytral apex. Length of the rostrum was measured from the apex of the rostrum (without mandibles) to the anterior edge 
of the eyes. Width of the rostrum is the maximum distance between lateral edges of the pterygia. All measurements were taken with an ocular micrometer.

Diagnostic characters were photographed using Canon EOS 5D Mark III camera attached to Canon 2,8/100 macro lens with extension tube (habitus), and Canon 2,8/20 lens with reversing ring (details). Series of images were processed by Helicon Focus automontage software, post work was made in Photoshop and Office Publisher. Type specimens of the new species were tagged with red labels indicating the holotype or paratype status, the name of the species, and the name of the author.

Six male and six female specimens were measured, and average measurements were calculated. The types and other studied material are deposited in the following collections: Hungarian Natural History Museum, Budapest, Hungary (HNHM), private collection of Attila Podlussány, Budapest, Hungary (PCAP), and private collection of Valentin Szénási, Isaszeg, Hungary (PCVS).

Abbreviations - FW/ELD = ratio between head capsule width and longitudinal eye diameter; $\mathrm{PL} / \mathrm{PW}=$ ratio of pronotum length to pronotum width; $\mathrm{EL} / \mathrm{EW}=$ ratio of length to width of elytra; $\mathrm{BL}=$ body length; $\mathrm{BW}=$ body width; $\mathrm{BH}=$ body height; $\mathrm{RL}=$ rostrum length; $\mathrm{RWA}=$ rostrum width at apex; $\mathrm{FW}=$ head capsule width (between eyes); ELD = longitudinal diameter of eye; $\mathrm{EL}=$ elytra length; $\mathrm{EW}=$ elytra width $\mathrm{PL}=$ pronotum length $\mathrm{PW}=$ pronotum width.

\section{Eptacus cylindriclavatus sp. $n$.}

(Figs 1-16)

Type material - Holotype, male. "SYRIA, gov. Homs, $30 \mathrm{~km}$ N Palmyra, semi-desert, hand collected from ground, $34^{\circ} 36^{\prime} 46.96^{\prime \prime} \mathrm{N}, 38^{\circ} 35^{\prime} 48.90^{\prime \prime} \mathrm{E}, 435 \mathrm{~m}$, 28.V.2010, leg. A. Kotán, E. Mizsei, T. Németh \& N. Rahmé" (HNHM). Paratypes: same as holotype ( 3 males, 4 females, PCAP; 1 female, HNHM; 1 male, 1 female, PCVS); "SYRIA, gov. Homs, Palmyra, oasis, hand collected from

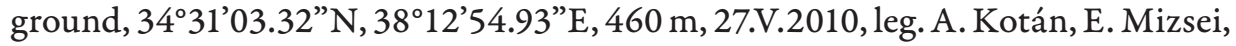
T. Németh \& N. Rahmé" (1 male, 3 females, PCAP; 1 male, 1 female, PCVS).

Diagnosis - Eptacus cylindriclavatus sp. n. (Figs 1-14) can be easily separated from its congeners by its distinctive cylindrical antennal club, which is $2.45 \times$ as long as wide, elongated and less punctate rostrum, and relatively large and bulged eyes.

Comparison with other species - Eptacus cylindriclavatus sp. n. can be easily separated from other Eptacus species of the region by its distinctive cylindrical club, which is $2.45 \times$ as long as wide (Fig. 5). The new species mainly differs from E. weilli weilli Pelletier, 2006 and E. weilli magnanoi Pelletier, 2006 (described also from Syria, near Palmyra, and Damascus) in its colour of the bristles of tibial apex (E. weilli weilli and E. weilli magnanoi: orange and yellowish, E. cylindriclavatus 
sp. n.: dark brown), slightly larger body size, hardly visible body vestiture, shape of rostrum, and shape of male genitalia. The rostrum of E. cylindriclavatus sp. n. almost parallel sided, the pterygia are weakly protruding (Fig. 4), while the rostrum of E. weilli weilli is markedly tapering forward, and the pterygia are more protruding. The tip of the penis of E. cylindriclavatus sp. n. is widely truncated (Fig. 10), while that of E. weilli weilli is tapering. E. cylindriclavatus sp. n. differs also from E. arachnoides (Stierlin, 1861), which is distinctly larger, more robust, the head and rostrum are wider, scape and funicle are markedly robust, the club is lanceolate, the eyes are smaller and less bulged. Eptacus arachniformis (Reitter, 1908) is also a larger and more robust species, and is easily separated from E. cylindriclavatus by its longer funicle segments I-IV. Eptacus kurdistanus (Stierlin, 1861) differs from E. cylindriclavatus sp. n. by its more elongated head and rostrum, larger and flat eyes, and more slender penis. The tip of the penis of E. kurdistanus is less wide than that of E.cylindriclavatus sp. n.

Description - Holotype, male (Figs 1-10). BL $7.10 \mathrm{~mm}$, BW $3.55 \mathrm{~mm}, \mathrm{BH}$ $2.75 \mathrm{~mm}$. Integument black, legs and antennae blackish-brown, dorsal surface almost glabrous, but lateral parts and apex of elytra with hardly visible sparse, recumbent setae directed backwards in regular rows.

Head: $1.2 \times$ longer than pronotum; rostrum nearly parallel-sided to pterygia, as wide as long (RL/RWA 1) (Fig. 4); entire surface is glabrous, but apex of rostrum with conspicuous bristles; pterygia weakly projecting in dorsal view; epifrons with slightly convex sides, dorsal part almost flat, with hardly visible, short and shallow median sulcus (extending mainly in antennal insertions), sparsely and finely punctate; forehead weakly convex, before eyes with shallow, transverse groove; in middle of posterior margin of groove with small, shallow interocular pit; frons sparsely punctate; epistome posteriorly surrounded by thin C-shaped carina; eyes moderately large and bulged (FW/ELD $2.4 \mathrm{~mm}$ ); vertex moderately convex, head capsule elongate, sparsely and finely punctate; scape slightly curved, gradually widened from base toward apex, sparsely covered with thin and recumbent dark brown hairs; funicle with seven segments covered with scarcely thin and recumbent darker hairs, and thicker and moderately curved, semierect seta-like dark brown scales; segment I long, $3 \times$ as long as wide, and $1.5 \times$ as long as segment II, which $2 \times$ as long as wide, III-IV as long as wide, V-VII disc-shaped; club distinctively cylindrical, $2.45 \times$ as long as wide, posterior and anterior parts similarly rounded, covered with fine dense recumbent and sparse erect hairs.

Pronotum: Longer than wide (PL/PW 1.25), widest at middle (Fig. 1). Punctation coarse, deep, densely covering posterior half of pronotal disc, coarse and deep, but not dense at sides of pronotum, and sparsely covering anterior half of pronotal disc; interspaces between punctures narrow, rather rugose mainly in posterior half of pronotal disc. Punctures bearing short and thin hair-like scales.

Elytra: Oblong-oval (EL/EW 1.4), widest at middle, scarcely convex in lateral view, steeply declined to posterior end. Base of elytra as wide as base of pronotum. 
Scales lacking. Striae well developed, punctures moderately deep, with hardly visible, short, sparse setae. Third stria in deep groove, with slightly distorted punctures and setae. Interstriae almost flat except interstriae III-IV slightly convex, others $2-3 \times$ as wide as striae, with hardly visible sparse, recumbent setae directed backwards in regular rows. Scutellum invisible.

Legs: Femora relatively slender, unarmed. Tibiae narrow, slightly curved. Protibiae sligthly widened at apex. Apex of all tibiae without mucro, and with dark brown bristles. Protarsomere I triangular, II transverse, III wide and bilobed, shorter than I and II combined, V 2.5X as long as III. Outer sides of legs covered with short, thin, recumbent dark brown setae, inner sides with longer, shorter, semierect dark brown setae.

Lateral part of body (epimera, episterna, lateral side of metaventrite), metaventrite mesally and abdominal ventrites $\mathrm{I}-\mathrm{V}$ with scattered, short, pale hairs, except apex of ventrite $\mathrm{V}$ which covered by scattered, longer, dark brown bristles. Ventrites III to V finely punctured. Ventrite V regularly rounded apically. Intercoxal process between hind coxae weakly concave (Fig. 3).

Male terminalia (Figs 6-10): Pygidium truncate, with dense, pale hairs at apex. Spiculum gastrale with fused basal arms, thick, almost straight (Fig. 6). Penis strong (Figs 8-9), median lobe stout, subparallel-sided in ventral view, slightly widened to apex, apex widely truncate, slightly longer than apodemes. In lateral view (Fig. 9) widened to middle, lateral edges of basal half strongly sclerotized. Internal sack without inner sclerit. Tegmen (Fig. 7) oval, without parameres, manubrium slightly curved, about $0.5 \times$ as long as apodeme of median lobe.

Female (Figs 11-14): Similar to male; body longer, wider, proportionally more elongate. Third protarsomere distinctly smaller and narrower than in male. Intercoxal process between hind coxae flat.

Female genitalia (Figs 13-14): Spiculum ventrale elongate, apodeme thin, apical margin of plate semicircular, sclerotised, with several long sensillae at apex. Spermatheca with C-shaped cornu, with acute apex, corpus scarcely bulged, ramus swollen, distinctly wider than cornu, collum scarcely bulged. Ovipositor with one pair of sclerotised gonocoxites, with styli and sensilla at apex.

Variability - Members of the genus Eptacus, including the new species, are highly variable. In many specimens of E. cylindriclavatus sp. n. the distinctive deep groove of the third elytral stria is less distinct or even absent. The specimens differ in pronotal punctation: in several specimens it is evenly coarse and dense. The surface of rostrum is also variable: with more or less developed median sulcus, and with punctation of varying strength and shape. Males: BL: 6.55-7.15 (average 6.87), BW: 3.25-3.55 (average 3.38), BH: 2.55-2.85 (average 2.67). Females BL: 7.00-7.65 (average 7.30), BW: 3.55-3.95 (average 3.68), BH: 2.852.95 (average 2.91).

Etymology - The specific epithet is derived from Latin cylindrus (= cylinder) and clavus (= club) referring to the distinctive cylindrical antennal club. 
Ecology - The specimens were collected by hand in the semidesert habitat near Palmyra, in central Syria (Figs 15-16).
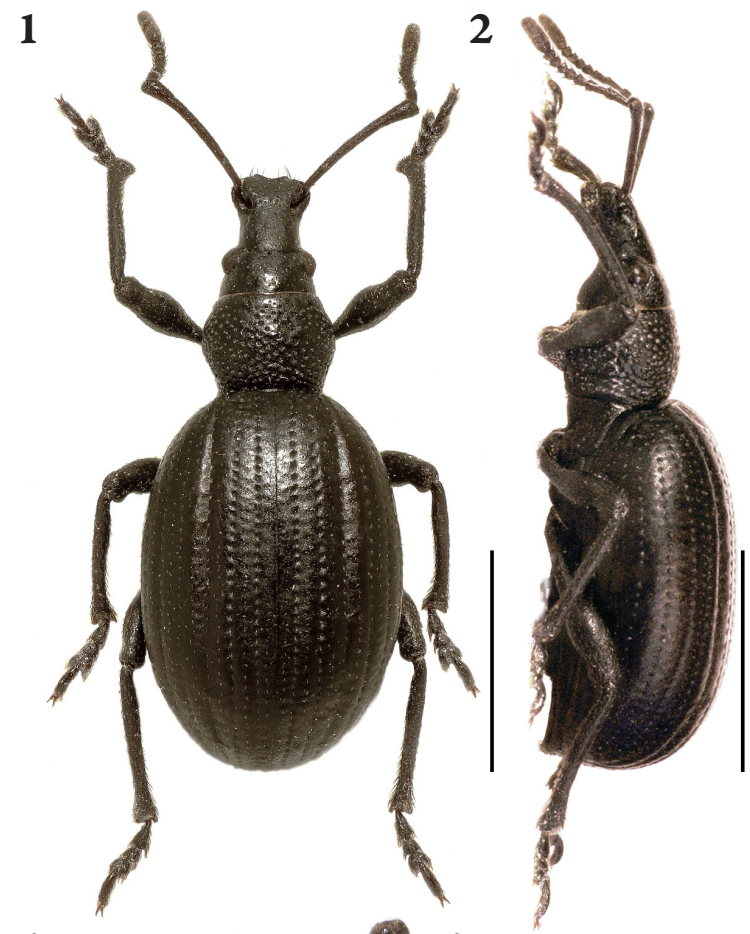

3
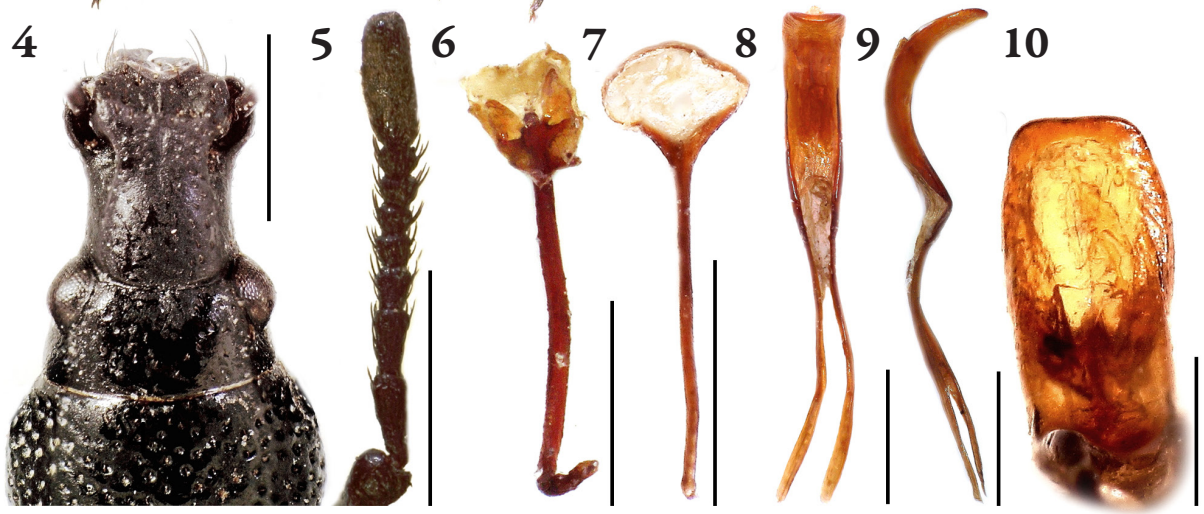

Figs 1-10. Eptacus cylindriclavatus sp. n. holotype, male: $1=$ dorsal view, $2=$ lateral view, $3=$ ventral view, $4=$ head, dorsal view, $5=$ antennal segments, $6=$ spiculum gastrale, $7=$ tegmen, $8=$ penis, ventral view, $9=$ penis, lateral view, $10=$ tip of penis. Scale bars for Figs $1-3=3.00 \mathrm{~mm}$, for Figs $4-9=1.00 \mathrm{~mm}$, for Fig. $10=0.50 \mathrm{~mm}$ (photos by Valentin Szénási) 

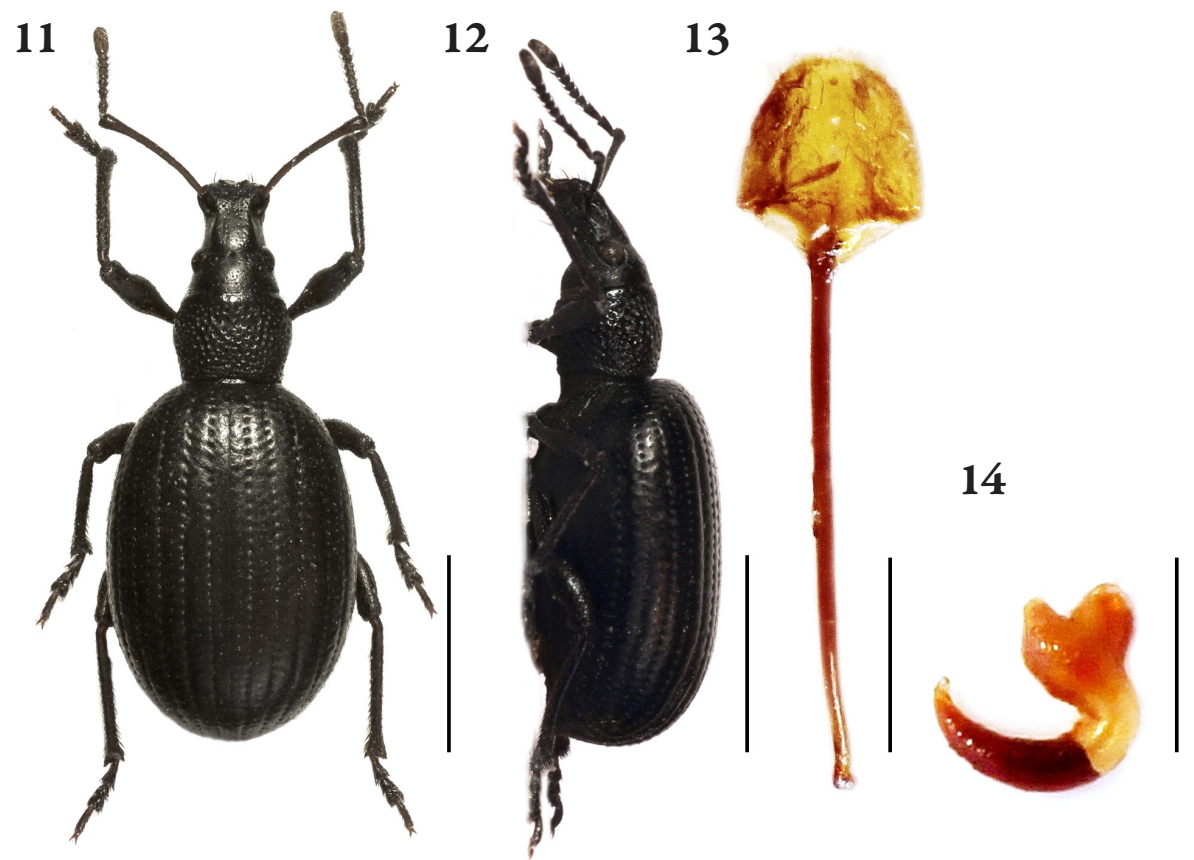

Figs 11-14. Eptacus cylindriclavatus sp. n., paratype, female: $11=$ dorsal view, $12=$ lateral view, $13=$ spiculum ventrale, $14=$ spermatheca. Scale bars for Figs $11-12=3.00 \mathrm{~mm}$, for Fig. $13=0.50 \mathrm{~mm}$, for Fig. $10=0.30 \mathrm{~mm}$ (photos by Valentin Szénási)
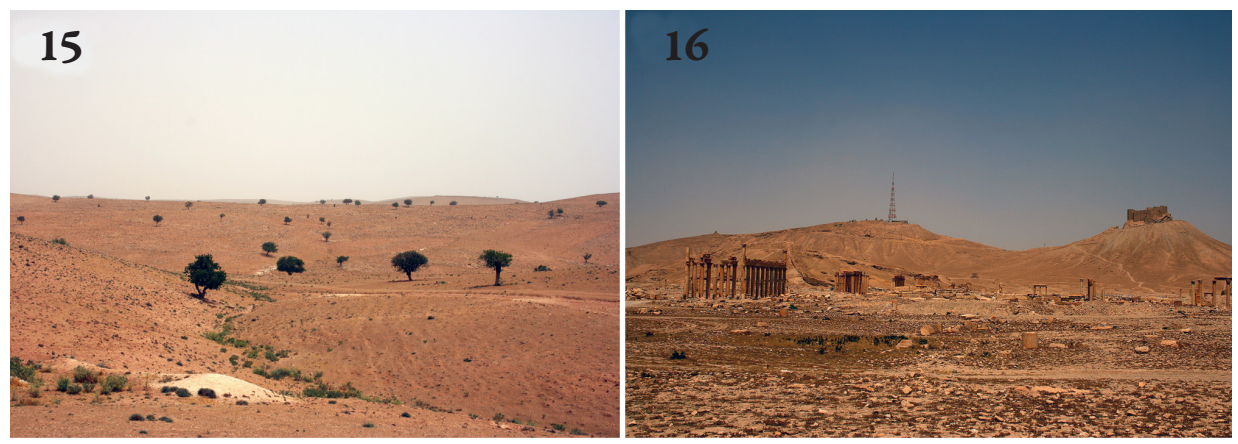

Figs 15-16. Habitat of Eptacus cylindriclavatus sp. n. near Palmyra in Central Syria (photos by Attila Kotán) 
Acknowledgements - Thanks are due to Ottó Merkl (senior curator, HNHM) for access to the HNHM Coleoptera Collection. I am grateful to Attila Kotán, Edvárd Mizsei, Tamás Németh, and Nikola Rahmé for collecting weevils for me. Special thanks are due to Ottó Merkl and Tamás Németh for comments on the manuscript.

\section{REFERENCES}

Alonso-Zarazaga M. A., Barrios H., Borovec R., Bouchard P., Caldara R., Colonnelli E., Gültekin L., Hlaváč P., Korotyaev B., Lyal C. H. C., Machado A., Meregalli M., Pierotti H., Ren L., Sánchez-Ruiz M., Sforzi A., Silfverberg H., Skuhrovec J., Trýzna M., Velázquez de Castro A. J. \& Yunakov N. N. 2017: Cooperative Catalogue of Palaearctic Coleoptera Curculionoidea. Monografías electrónicas SEA, vol. 8. - Sociedad Entomológica Aragonesa (S. E. A.), Zaragoza, 729 pp.

Emden F. van 1928: Zwei neue Eptacus aus Syrien (Col. Curc.). - Entomologische Blätter 24: $120-124$.

Lona C. 1939: Zwei neue Curculioniden-Arten der Paläarktischen Fauna. (Col.) - Arbeiten über Physiologische und Angewandte Entomologie aus Berlin-Dablem 6: 315-317.

Lyal C. H. C. 2019: Glossary of Weevil Characters. International Weevil Community Website. Available from: http: //weevil.info/glossary-weevil-characters [Accessed 9 July 2020).

MARSeul S. A. DE 1868: Voyage en Syrie. Description des espèces nouvelles. - L'Abeille 5: 171-218.

Pelletier J. 2006: Révision du genre Eptacus Desbrochers, 1908 (Coleoptera, Curculionidae, Entiminae). - Bulletin de la Société Entomologique de France 111: 207-221.

Pelletier J. 2012: Analyse critique de la tribu des Holcorhinini Desbrochers (sensu Reitter, 1913) de la région paléarctique (Coleoptera, Curculionidae, Entiminae). - Nouvelle Revue d'Entomologie (N. S.) 28: 11-25.

Peyerimhoff P. DE 1907: Liste des Coléoptères du Sinaï. - L'Abeille 31: 1-47.

Reitter E. 1908: Beschreibung einiger neuen Käferarten von Egypten. - Bulletin de la Société entomologique d'Egypte 1: 41-56.

STIERLIN W. G. 1861: Revision der europäischen Otiorhynchus-Arten. - Berliner Entomologische Zeitschrift 5: 1-344. 